\title{
Pengaruh Aplikasi Core Math Tools Terhadap Kemampuan Visual Thinking Matematik Siswa
}

\author{
Dedek kustiawati ${ }^{1}$, Gelar dwirahayu ${ }^{2,}$ Mauludin hafiz alhadi ${ }^{3}$ (Arial,10 font size) \\ ${ }^{1}$ Dosen Pendidikan Matematika FITK UIN Syarif Hidayatullah \\ dedek.kustiawati@uinjkt.ac.id \\ ${ }^{2}$ Dosen Pendidikan Matematika FITK UIN Syarif Hidayatullah \\ gelar.dwirahayu@uinjkt.ac.id \\ ${ }^{3}$ Dosen Pendidikan Matematika FITK UIN Syarif Hidayatullah \\ Hafiz.bacil@gmail.com
}

\begin{abstract}
Abstrak
Tujuan penelitian adalah untuk menganalisis kemampuan visual thinking matematik siswa yang diajarkan dengan media aplikasi core math tools dan yang diajarkan dengan pembelajaran konvensional serta menganalisis perbedaan kemampuan visual thinking matematik antar siswa yang diajarkan dengan media aplikasi core math tools dan siswa yang diajar dengan media pembelajaran konvensional. Penelitian ini dilakukan di MAN 19 Jakarta Tahun Ajaran 2015/2016. Metode yang digunakan adalah metode quasi eksperimen dengan desain penelitian Randomized Control Group Posttest Only, yang melibatkan 70 siswa sebagai sampel. Penentuan sampel menggunakan teknik cluster random sampling. Hasil penelitian mengungkapkan bahwa kemampuan visual thinking matematik siswa yang diajar dengan media aplikasi core math tools lebih tinggi dari pada siswa yang diajar dengan media pembelajaran kovensional. Hal ini dapat dilihat dari nilai rata-rata hasil tes kemampuan visual thinking matematik siswa yang diajar dengan media aplikasi core math tools adalah sebesar 60,89 dan nilai rata-rata hasil tes kemampuan visual thinking matematik siswa yang diajar dengan media pembelajaran konvensional adalah sebesar 41,61 (thitung = 5,39 dan ttabel =2,00). Kesimpulan hasil penelitian ini adalah bahwa pembelajaran matematika pada pokok bahasan Menggambar Grafik Trigonometri dengan menggunakan media aplikasi core math tools berpengaruh secara signifikan terhadap kemampuan visual thinking matematik siswa dibandingkan pembelajaran konvensional.
\end{abstract}

Kata kunci : Aplikasi Core Math Tools, Kemampuan Visual Thinking Matematik Siswa.

\section{PENDAHULUAN}

Matematika berperan penting bagi kehidupan sehari-hari guna menghadapai kemajuan teknologi dan perkembangan ilmu masa kini. Untuk itu ilmu matematika perlu diajarkan sejak dini sebagai bekal dimasa depan. Disisi objek matematika yakni benda abstrak, artinya hanya ada didalam pikiran manusia. Pada materi submateri menggambar grafik fungsi trigonometri, Nurul dan Tatag (2015) guru mengajarkan bagaimana cara menggambar grafik fungsi $\mathrm{y}=\sin \mathrm{x}, \mathrm{y}=\cos \mathrm{x}$, dan $\mathrm{y}=\tan \mathrm{x}$ pada bidang koordinat cartesius. Cara menggambar grafik trigonometri dapat dengan mencari titik-titik koordinat yang dilalui grafik dengan mensubstitusikan sudut istimewa ke dalam variabel x pada rumus fungsi trigonometri yang dimaksud. Selain itu menggambar grafik fungsi trigonometri juga dapat menggunakan bantuan titik puncak dan titik potong grafik terhadap sumbu koordinat atau dengan menggunakan karakteristik nilai maksimum-minimum, periode dan pergeseran fase dari grafik fungsi trigonometri. Dalam hal ini siswa harus melihat keterkaitan antara karakteristik yang ada pada fungsi dengan karakteristik yang ada pada grafik, dengan kata lain siswa perlu memiliki kemampuan visualisasi yang baik untuk memahami konsep menggambar grafik fungsi trigonometri.

Menurut Sahat dan Vira (2012: 369) kenyataan dilapangan masih banyak siswa yang tidak memahami konsep menggambar grafik fungsi trignometri. Misalnya, ketika siswa diminta untuk menggambar atau membaca grafik fungsi trigonometri, siswa tidak mampu menggambarnya dengan benar, sehingga tidak dapat memberikan alasan atau penjelasan yang benar atas grafik tersebut. Hal ini diduga bahwa siswa tidak memiliki kemampuan visualisasi yang baik dalam melihat karakteristik pada fungsi trigonometri dan karakteristik pada grafik trigonometri. Dalam fakta dilapangan menunjukan bahwa masih banyak siswa yang tidak memahami konsep menggambar grafik fungsi trignometri. Siswa tidak memiliki kemampuan visualisasi yang baik dalam melihat karakteristik pada fungsi trigonometri dan karakteristik pada grafik trigonometri. Hal tersebut yang menyebabkan kemampuan visual thinking matematik siswa rendah. 
Selain itu kemampuan visual thinking memiliki hubungan dengan pemahaman konsep matematika, kemampuan visualisasi siswa memberi pengaruh terhadap pemahaman konsep. Kemampuan visual thinking siswa adalah kegiatan berpikir dengan membayangkan, mempresentasikan, menggunakan berbagai bentuk matematis yaitu visual (grafik, diagram, tabel, dan gambar). Untuk itu sangat perlu sekali kemampuan visual thinking matematik ditanamkan kepada siswa.

Menurut Edy Surya(2013:1) Visualisasi memiliki peran penting dalam transisi dari berpikir konkrit ke abstrak. Yin (2015:3) mengindentifikasi peran visualisasi : (1) memahami permasalahan, (2) menyederhanakan permasalahan, (3) melihat koneksi antar masalah, (4) memenuhi gaya belajar individu, (5) sebagai pengganti perhitungan, (6) sebagai alat memeriksa jawaban, dan (7) untuk mengubah masalah kedalam bentuk matematis. Hasil penelitian Dwirahayu dalam Gumanti (2014:6) menunjukan bahwa ada keterkaitan antara kemampuan visualisasi dan pemahaman konsep, dimana kemampuan visualisasi siswa memberi pengaruh terhadap pemahaman konsep. Sehingga lemahnya kemampuan visual thinking akan menyebabkan siswa mengalami kesulitan dalam menyelesaikan masalah matematis, karena itu kemampuan visual thinking sangat penting untuk ditingkatkan.

Salah satu faktor penyebab rendahnya kemampuan berpikir siswa adalah proses pembelajaran yang dilakukan guru dan siswa di kelas. Pembelajaran grafik fungsi trigonometri di kelas masih tergolong konvensional, guru hanya menggunakan media papan tulis dan belum banyak yang memanfaatkan media pembelajaran seperti komputer. Hal tersebut membuat pembelajaran kurang efisien dan beberapa siswa sulit menangkap materi yang disampaikan. Untuk itu diperlukan media lain yang dapat membantu siswa untuk mempelajari grafik dengan lebih mudah, efisien, dan membantu pemahaman siswa tentang materi grafik fungsi kuadrat. Ketika mempelajari grafik fungsi trigonometri guru lebih memilih menggambarnya di papan tulis dan siswa menggambar di bukunya masing-masing. Tentunya cara ini memakan waktu lama dan siswa hanya menggambar sedikit contoh grafik fungsi trigonometri tersebut. Dengan mengandalkan apa yang disampaikan guru, tak jarang siswa lupa atau bingung ketika diminta menggambarkan kembali atau menuliskan persamaan fungsi dari gambar grafik yang tersedia.

Teknologi kini semakin maju dan banyak dipergunakan dalam kehidupan sehari-hari. penting bahwa guru dan siswa memiliki akses rutin ke teknologi yang mendukung dan memajukan pemahaman matematika, penalaran, pemecahan masalah, dan komunikasi. Christian Hirsch, dkk (2015:1) Salah satu teknologi yang tidak asing bagi kalangan orang adalah internet. Indonesia merupakan negara dengan jumlah pengguna internet dan sosial media terbesar di dunia dengan mencapai 88,1 juta. Menurut Adhi Maulana Internet juga dapat dimanfaatkan pada kegiatan belajar mengajar disekolah. PT. Telekomunikasi Indonesia (TELKOM) telah membuat program bernama IndiSchool yang merupakan program penyediaan Internet WiFi di sekolahsekolah untuk membantu meningkatkan kualitas pendidikan. Pada tahun 2013, secara nasional Telkom telah menggelar sebanyak 10.898 titik IndiSchool di Indonesia. Menurut Sahat dan Vira (2012:370) penggunaan komputer di sekolah-sekolah masih belum dioptimalkan, terutama saat belajar matematika. Bahkan ada guru yang menentang penggunaan media berbasis Information and Communication Technology (ICT) dalam pembelajaran matematika dikarenakan waktu dan ketidakmampuan memanfaatkan media tersebut. Rendahnya pengetahuan guru dalam pemanfaatan media komputer dan software matematika menjadi salah satu faktor tidak digunakannya ICT dalam pembelajaran matematika.

National Council of Teacher of Mathematics (NCTM) dalam webside-nya (www.nctm.or.id) mempersembahkan aplikasi atau software gratis berbasis internet bernama Core Math Tools. Core Math Tools menyediakan alat atau media unik yang dapat digunakan baik oleh guru maupun siswa dalam pembelajaran matematika dikelas maupun diluar kelas. Alat atau media didalamnya meliputi: spreadsheet, sistem aljabar komputer, geometri interaktif (dinamis), analisis data, dan alat simulasi serta dilengkapi dengan Custom Apps dan Advanced Apps untuk materi kongruensi atau kesamaan segitiga, pemodelan data, program linear, visualisasi tiga dimensi dan lainya.

Sebaliknya jika menggunakan Core Math Tools siswa dapat berulang kali mencoba menghasilkan banyak contoh grafik fungsi trigonometri, sampai akhirnya siswa dapat melihat sendiri simpulan tentang bagaimana gambar grafik sinus, grafik cosinus dan grafik tangent; berapa nilai maksimum dan minimumnya; apa keterkaitan antara fungsi trigonometri dengan grafiknya; dan jika siswa ragu siswa dapat mencoba lagi berulang kali sampai yakin dan terbukti benar simpulan yang diambilnya. Dengan demikian siswa akan terlatih memvisualkan fungsi trigonometri kedalam bentuk grafik, ataupun sebaliknya. Core math tools (CMT) adalah sebuah media interaktif pembelajaran matematika yang berupa perangkat lunak atau software yang dapat digunakan guru dalam mengajar di kelas secara gratis. CMT merupakan alat bantu pembelajaran matematika untuk mendukung pemahaman konsep matematika secara kontektual. CMT akan membantu siswa dalam menggambarkan grafik fungsi trigonometri dengan efektif dan waktu yang efisien. Dengan menggunakan Core Math Tools siswa dapat berulangkali mencoba-coba menghasilkan banyak contoh grafik fungsi trigonometri, sampai akhirnya siswa dapat melihat sendiri simpulan tentang bagaimana gambar grafik sinus, grafik cosinus, grafik tangen, berapa nilai maksimum dan minimumnya, apa keterkaitan antara fungsi 
trigonometri dengan grafiknya dan jika siswa ragu siswa dapat mencoba lagi berulang kali sampai yakin dan terbukti benar simpulan yang diambilnya. Dengan membiasakan menggambarkan atau memvisualisasikan grafik fungsi trigonometri dengan CMT, siswa akan dapat menemukan konsep tentang grafik fungsi trigonometri. Dengan demikian akan melatih kemampuan visual thinking siswa.

Peneliti ingin membuktikan apakah kemampuan visual thinking matematika siswa yang diajarkan menggunnakan media core math tools (CMT) akan lebih tinggi dibandingkan siswa yang diajarkan dengan media konvensional.

\section{METODE PENELITIAN}

Penelitian ini mengunakan metode eksperimen semu (quasi eksperimen) karena peneliti tidak dapat sepenuhnya mengontrol variable-variabel luar yang mempengaruhi penelitian. Pada penelitian ini sampel dikelompokan menjadi dua dan diberikan perlakuan pembelajaran yang berbeda yaitu kelompok eksperimen dengan menggunakan media pembelajaran Core Math Tools dan kelompok kontrol diberikan perlakuan media pembelajaran secara konvensional.

Desain eksperimen yang digunakan dalam penelitian ini berbentuk two group randomized subject posttest only artinya pengkontrolan secara acak dengan tes hanya diakhir perlakuan. Desain Penelitia Sugiono (2013:114) dinyatakan sebagai berikut:

Tabel 3.1 Desain Penelitian

\begin{tabular}{|l|l|l|l|}
\hline & Kelompok & Treatment (perlakuan) & $\begin{array}{l}\text { Postest } \\
\text { (tes akhir) }\end{array}$ \\
\hline$(\mathrm{R})$ & $\mathrm{E}$ & $\mathrm{XE}$ & $\mathrm{Y}$ \\
\hline$(\mathrm{R})$ & $\mathrm{K}$ & $\mathrm{XK}$ & $\mathrm{Y}$ \\
\hline
\end{tabular}

Keterangan:

R : Random

E : Kelompok kelas eksperimen

$\mathrm{K} \quad$ : Kelompok kelas kontrol

XE : Perlakuan dengan pembelajaran menggunakan media aplikasi Core Math Tools

XK : Perlakuan dengan pembelajaran menggunakan media konvensional

Y : Test akhir yang sama pada kedua kelas

Rancangan ini terdiri atas dua kelompok, satu kelompok eksperimen diberikan perlakuan pembelajaran menggunakan media aplikasi Core Math Tools dan satu kelompok kontrol yang diberikan perlakuan dengan media konvensional. Pada keduanya dilakukan pasca-uji yaitu menguji tingkat kemampuan visual thinking dan hasilnya dibandingkan.

Populasi dalam penelitian ini adalah seluruh siswa kelas X (sepuluh) MAN 19 Jakarta pada semester genap tahun ajaran 2015/2016 yang terbagi kedalam tiga kelas. Teknik pengambilan sampel yang digunakan adalah teknik Cluster Random Sampling. Teknik ini mengambil 2 kelas dari seluruh kelas yang ada. Kemudian dari 2 kelas tersebut diundi, kelas mana yang akan dijadikan kelas eksperimen dan control, maka terpilih kelas X MIA 2 dengan jumlah siswa 36 orang sebagai kelas eksperimen dan kelas X MIA 3 dengan jumlah siswa 34 orang sebagai kelas kontrol.

Tes kemampuan visual thinking yang diberikan terdiri dari 15 butir soal berbentuk pilihan ganda dengan pokok bahasan Grafik Fungsi Trigonometri. Pelaksanaan tes kemampuan visual thinking siswa dilakukan di akhir penelitian. Berdasarkan definisi operasional kemampuan visual thinking siswa, kisi-kisi instrumen tes kemampuan visual thinking siswa dapat dilihat pada tabel 3.2.

Tabel 3.2 Kisi-Kisi Instrumen Tes Kemampuan Visual Thinking Matematika Kompetensi Dasar Mendeskripsikan konsep fungsi Trigonometri dan menganalisis grafik fungsinya serta menentukan hubungan nilai fungsi Trigonometri dari sudut- sudut istimewa.

\begin{tabular}{|l|l|}
\hline Indikator Kemampuan Visual Thinking & Nomor Soal \\
\hline $\begin{array}{l}\text { Mampu mempresentasikan permasalahan dari bentuk } \\
\text { abstrak (fungsi) ke bentuk visual (grafik). }\end{array}$ & $1,4,5,7,10,11,15$ \\
\hline $\begin{array}{l}\text { Mampu mempresentasikan permasalahan dari bentuk } \\
\text { visual (grafik) ke bentuk abstrak (fungsi). }\end{array}$ & $2,3,6,8,9,12,13,14$ \\
\hline
\end{tabular}


Berdasarkan hasil perhitungan uji validitas instrumen penelitian, dari 15 butir soal yang diujicobakan diperoleh 15 butir soal yang valid. Perhitungan selengkapnya mengenai uji validitas instrumen penelitian dapat dilihat pada lampiran. Berdasarkam kriteria koefisienreliabilitas, nilai $r_{i}=0,832$ berada di kisaran $0,80<r_{i} \leq 1,00$, maka soal-soal tersebut memiliki derajat reliabilitas sangat baik.

\section{HASIL PENELITIAN DAN PEMBAHASAN}

\section{Hasil Penelitian}

Penelitian mengenai kemampuan visual thinking matematik siswa ini dilakukan di MAN 19 Jakarta terhadap dua kelas sebagai sampel, yaitu kelas X MIA 2 sebagai kelas eksperimen dan kelas X MIA 3 sebagai kelas kontrol. Pada penelitian ini kelas eksperimen yang terdiri dari 36 orang siswa diajarkan materi menggambar grafik trigonometri dengan menggunakan media aplikasi core math tools sedangkan kelas kontrol yang terdiri dari 34 orang siswa diajarkan materi menggambar grafik trigonometri dengan media pembelajaran konvensional. Setelah diberikan perlakuan yang berbeda antara kelompok eksperimen dan kelompok control, kedua kelompok diberikan tes kemampuan visual thinking matematik siswa.

Perbandingan Skor Kemampuan Visual Thinking Matematik Siswa Kelompok Eksperimen dan Kelompok Kontrol. Pebandingan kemampuan visual thinking matematik siswa antara kelompok eksperimen yang dalam pembelajarannya menggunakan media aplikasi core math tools dengan kelompok kontrol yang dalam pembelajarannya menggunakan media pembelajaran konvensional dapat kita lihat pada tabel 4.3 berikut:

Tabel 4.1 Perbandingan Kemampuan Visual Thinking Matematik Siswa Kelompok Eksperimen dan Kelompok Kontrol

\begin{tabular}{|l|l|l|}
\hline \multirow{2}{*}{ Statistik Deskriptif } & Kelompok \\
\cline { 2 - 3 } & Eksperimen & Kontrol \\
\hline Jumlah sampel $(\mathrm{n})$ & 36 & 34 \\
\hline Maksimum $($ Xmaks) & 94 & 74 \\
\hline Minimum $($ Xmin) & 20 & 14 \\
\hline Mean $(\bar{x})$ & 60,89 & 41,61 \\
\hline Median $\left(M_{e}\right)$ & 60,5 & 43,07 \\
\hline Modus $\left(M_{o}\right)$ & 57,1 & 44 \\
\hline Varians $\left(S^{2}\right)$ & 265,82 & 178,24 \\
\hline Simpangan Baku $(S)$ & 16,304 & 13,35 \\
\hline Kemiringan $\left(\alpha_{3}\right)$ & 0,232 & $-0,178$ \\
\hline Ketajaman $\left(\alpha_{4}\right)$ & 0,27 & 0,18 \\
\hline
\end{tabular}

Dari tabel 4.1 dapat terlihat perbedaan statistika baik pada kelompok eksperimen maupun kelompok kontrol, dapat dijelaskan bahwa dari 36 siswa kelompok eksperimen dan 34 siswa kelompok kontrol. Nilai rata-rata $(\bar{x})$ yang diperoleh kelompok eksperimen lebih tinggi dibandingkan dengan kelompok kontrol dengan selisih 19,28 $\left(60,89\right.$ - 41,61), begitu pula dengan nilai median $\left(M_{e}\right)$ serta nilai modus $\left(M_{o}\right)$, yaitu pada kelompok eksperimen memperoleh nilai lebih tinggi dibandingkan pada kelompok kontrol. Jika dilihat dari simpangan baku, skor kemampuan visual thinking matematik siswa kelompok eksperimen lebih merata dan menyebar dibanding kelompok kontrol. Tingkat kemiringan di kelompok eksperimen -0,232. Karena berharga positif, maka distribusi data miring positif atau landai kanan. Dengan kata lain kecenderungan data mengumpul di bawah nilai rata-rata. Sedangkan pada kelompok kontrol memperoleh tingkat kemiringan 0,178. Karena berharga negatif, maka distribusi data miring negatif atau landai kiri. Dengan kata lain kecenderungan data mengumpul di atas nilai rata-rata. Ketajaman/kurtosis pada kelompok eksperimen maupun kelompok control adalah kurang dari 3, maka model kurva adalah datar (platikurtis) data tidak terlalu mengelompok.

Secara visual perbandingan penyebaran data di kedua kelompok yaitu kelompok eksperimen yang diterapkan pembelajaran dengan media aplikasi core math tools dan kelompok kontrol yang diterapkan media pembelajaran secara konvensional dapat dilihat pada diagram 4.1 di bawah ini: 


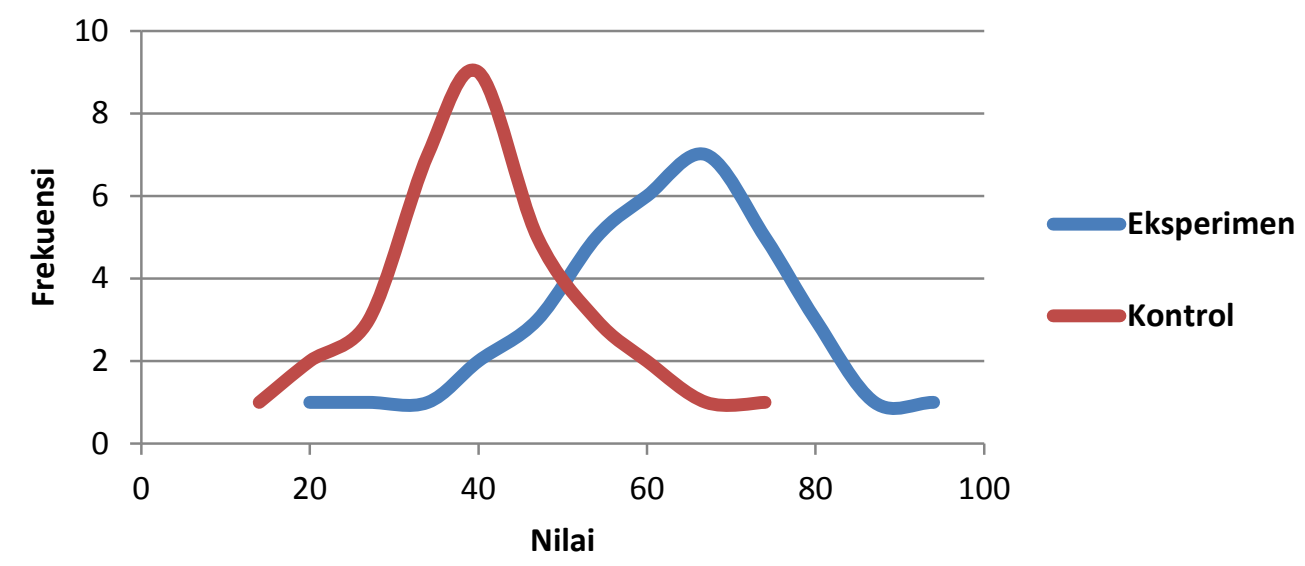

\section{Gambar 4.1 Kurva Perbandingan Nilai Kemampuan Visual Thinking Matematik Siswa Kelompok Kontrol dan Kelompok Eksperimen}

Berdasarkan kurva di atas, penyebaran nilai kemampuan visual thinking matemtik siswa pada kelompok eksperimen $(60,89)$ cenderung mengumpul di atas nilai rata-rata kelompok kontrol $(41,61)$. Pencapaian nilai maksimum siswa pada kelompok ekperimen (94) berada diatas nilai maksimum siswa pada kelompok kontrol (74) dan nilai minimum kelompok eksperimen (20) lebih tinggi dibandingkan nilai minimum kelompok kontrol (14). Hal tersebut menunjukan bahwa kemampuan visual thiking matematik siswa kelompok eksperimen lebih tinggi dibandingkan kemampuan visual thinking matematik siswa kelompok kontrol.

Pengujian dilakukan dengan uji-t. Setelah melakukan perhitungan dengan menggunakan uji-t untuk sampel yang homogen, maka diperoleh thitung = 5,39. Menggunakan tabel distribusi t pada taraf signifikansi $5 \%$, atau $\alpha=0,05$ diperoleh harga ttabel $=2,00$. Hasil perhitungan uji hipotesis disajikan pada tabel berikut ini.

Tabel 4.2 Hasil Uji-t

\begin{tabular}{|l|l|l|}
\hline thitung & ttabel $(\alpha=0,05)$ & Kesimpulan \\
\hline 5,39 & 2,00 & Tolak HO \\
\hline
\end{tabular}

Berdasarkan tabel 4.2 terlihat thitung lebih besar dari ttabel $(5,39>2,00)$ maka dapat disimpulkan bahwa H0ditolak dan $\mathrm{H} 1$ diterima dengan taraf signifikansi 5\%. maka dapat ditarik kesimpulan bahwa $\mathrm{H}_{0}$ ditolak, sedangkan $\mathrm{H}_{1}$ diterima. $\mathrm{H}_{1}$ menyatakan bahwa rata-rata kemampuan visual thinking matematik siswa yang pembelajarannya menggunakan media pembelajaran aplikasi core math tools lebih tinggi dari pada siswa yang menggunakan media pembelajaran konvensional dengan taraf signifikansi $5 \%$.

\section{Pembahasan}

Pada hasil analisis penelitian ini diketahui bahwa terdapat perbedaan rata-rata kemampuan visual thinking matematik siswa yang signifikan antara kelompok eksperimen dan kelas kontrol. Dimana perbedaan tersebut menunjukan bahwa kemampuan visual thinking matematik siswa yang diajarkan dengan menggunakan media pembelajaran core math tools lebih tinggi dibandingkan kemampuan visual thinking matematik siswa yang diajarkan dengan media konvensional. Kenyataan ini menunjukan bahwa penggunaan media aplikasi core math tools memberikan hasil yang lebih baik terhadap kemampuan visual thinking matematik.

Pembelajaran dengan media aplikasi core math tools dapat membantu siswa dalam memberikan visualisasi yang akurat, cepat, dan fleksibel dalam proses pembuatan grafik trigonometri. Dalam pembelajarannya, siswa membuat grafik pada aplikasi core math tools kemudian siswa menggambarkanya kembali dalam lembar kerja siswa (LKS) yang telah disediakan. Siswa juga menuliskan kesimpulan untuk setiap simulasi atau percobaan yang telah dilakukan pada aplikasi core math tools. Berikut gambar 4.2 adalah dokumentasi pada saat pembelajaran berlangsung dan salah satu hasil kerja siswa pada LKS. 

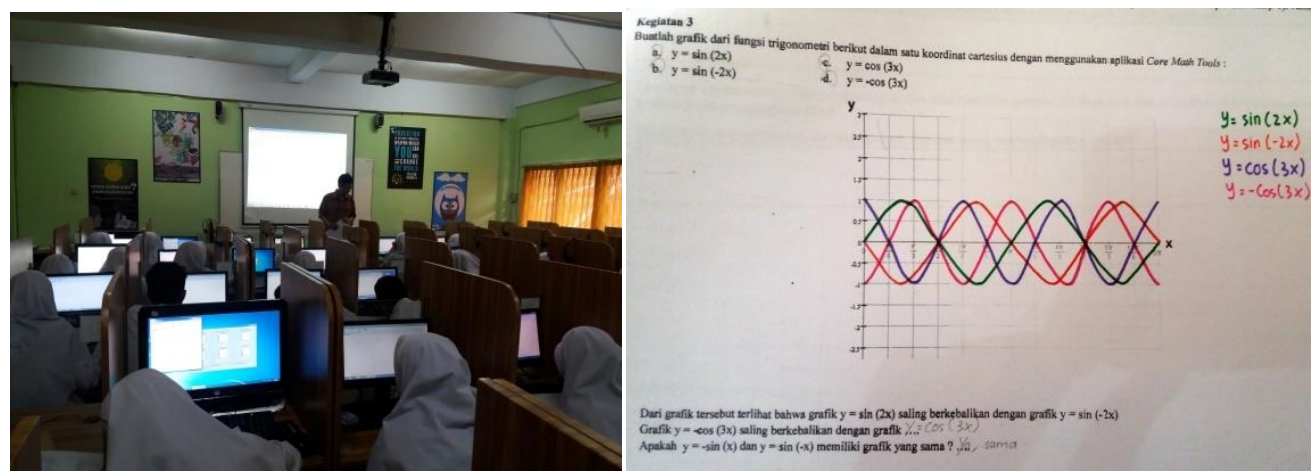

Gambar 4.2 Dokumentasi Proses Pembelajaran dan LKS

Berdasarkan temuan-temuan diatas, baik secara keseluruhan mupun dari aspek indikator kemampuan visual thinking matematiks siswa, menunjukan bahwa kemampuan visual thinking matematik siswa setelah diajarkan dengan media aplikasi core math tools secara signifikan memberikan pengaruh lebih baik dari pada kemampuan visual thinking matematik siswa yang diajarkan dengan media pembelajaran konvensional.

\section{KESIMPULAN}

Bagian ini menjelaskan kesimpulan umum dari hasil penelitian sesuai dengan tujuan penelitian. Berdasarkan hasil analisis dan pembahasan mengenai pembelajaran matematika dengan menggunakan media aplikasi core math tools terhadap kemampuan visual thinking matematik siswa di MAN 19 Jakarta diperoleh kesimpulan:

1. Kemampuan visual thinking matematik siswa yang menggunakan pembelajaran dengan media aplikasi core math tools pada umumnya sudah tergolong baik, hal tersebut terlihat dari rata-rata hasil tes kemampuan visual thinking matematik siswa yaitu sebesar 60,89.

2. Kemampuan visual thinking matematik siswa yang diajar dengan media aplikasi core math tools lebih tinggi dari pada kemampuan visual thinking matematik siswa yang diajar dengan media pembelajaran konvensional. Hal ini terlihat dari pengujian hipotesis dengan taraf signifikan 5\%, atau ( $\alpha=0,05)$ menghasilkan thitung lebih besar dari ttabel $(5,39>2,00)$. Dengan demikian, kemampuan visual thinking matematik siswa yang diajarkan dengan media aplikasi core math tools lebih tinggi dari pada siswa yang diajar dengan media pembelajaran konvensional.

\section{DAFTAR PUSTAKA}

Cristian Hirsch.(2012), Core Math Tools: Supporting Inquiry, Conceptual Understanding, and Problem Solving, NCTM Regional Conference, Dallas,. Tersedia online : http://www.nctm.org/coremathtools/

Gumanti, Sri.(2014). "Pengaruh Pembelajaran Berbantuan Geogebra terhadap Peningkatan Kemampuan Pemahaman dan Visual Thinking Siswa SMP”, Tesis pada UPI Bandung : tidak dipublikasikasi

Istiqomah,Nurul., dan Tatag Yulieko siswono. (2015).“Penalaran Siswa dalam Menggambar grafik fungsi Trigonometri Di tTinjau Dari Perbedaan Kemampuan Siswa“. jurnal Online Universitras Negeri Surabaya.

http://ejournal.Unesa.ac.id dan http://dokumen.tips/documents/penalaran-siswa-dalam-menggambar-grafik-fungsitrigonometri-ditinjau-dari-perbedaan.html

Christian Hirsch, dkk., Core Math Tools: Supporting Equitable Implementation of the Common Core State Standards for Mathematics, IGI Global, 2013, h. 2.

Maulana, Adhi. "Jumlah Pengguna Internet Indonesia Capai 88,1 Juta". http://tekno.liputan6.com/read/2197413/jumlah-pengguna-internet-indonesia-capai-881-juta, 1 Februari 2016.

Saragih, Sahat., dan Afriati, Vira. Peningkatan Pemahaman Konsep Grafik Fungsi Trigonometri Siswa SMK Melalui Penemuan Terbimbing Berbantuan Software Autograph. Jurnal Kemendikbud. 2012. http://dokumen.tips/documents/jurnal-pemahaman-konsep.html

Sugiyono. (2013). Metode Penelitian Pendidikan Pendekatan Kuantitatif, Kualitatif, dan R\&D, Cet. XIX, Alfabeta : Bandung 
Surya, Edy.(2013). "Peningkatan Kemampuan Representasi Visual Thinking pada Pemecahan Masalah Matematis dan Kemandirian Belajar Siswa SMP melalui Pembelajaran Kontekstual", Disertasi pada Pascasarjana UPI Bandung: tidak dipublikasikan.

Sword. "The power of visual thinking", www.giftedservice.com.au/handouts/index.html. 23 Oktober 2015.

TELKOM. "Lebih Dari 10 Ribu Sekolah di Indonesia Sudah Ter-cover IndiSchool". http://www.telkom.co.id/lebih-dari-10-ribu-sekolah-di-indonesia-sudah-ter-cover-indischool.html, 1 Februari 2016.

Yin, Siew. "Seeing the value of visualization". http://www.singteach.nie.edu.sg/wpcontent/uploads/SingTeach_Issue22.pdf, 23 Desember 2015. 